\title{
Acceptable surface temperature of floor radiant heating system based on thermal comfort study in southern China
}

\author{
Xingyu $\mathrm{Lu}^{1,2}$, Hong Liu, ${ }^{1,2}$, and Yuxin $\mathrm{Wu}^{1,2}$ \\ ${ }^{1}$ Joint International Research Laboratory of Green Buildings and Built Environments (Ministry of Education), Chongqing University, \\ Chongqing, China \\ ${ }^{2}$ National Centre for International Research of Low-carbon and Green Buildings (Ministry of Science and Technology), Chongqing \\ University, Chongqing, China
}

\begin{abstract}
In winter, people's demand for heating is stronger and stronger in southern China, and the floor radiant heating system is more and more popular. However, there are no suitable guidelines or standards for the floor temperature of the heating system in this area. The insulation performance of buildings in southern is not as good as other area which have central heating system. So the acceptable floor temperature suitable for this area needed to be studied. 12 healthy college students participated as samples in this experiment. The floor surface temperature was controlled by varying the temperature of water flowing underneath the floor. The main conclusions were as follows: 1) the floor surface temperature directly affected the skin temperature of the foot and the thermal comfort of the foot. There was a significant statistical relationship between the floor surface temperature and the overall thermal sensation. 2) The acceptable floor temperature ranged from $26.1{ }^{\circ} \mathrm{C}$ to $34.3{ }^{\circ} \mathrm{C}$ for sitting positions and $24.6{ }^{\circ} \mathrm{C} \sim 34.7{ }^{\circ} \mathrm{C}$ for standing positions. 3 ) Considering the head thermal comfort and the health effects of the cumulative effect of long-term heat exposure, the recommended upper limit of the floor temperature in this experiment is $31^{\circ} \mathrm{C}$.
\end{abstract}

\section{Introduction}

In southern China, with the frequent occurrence of extreme cold weather, people's demand for heating is getting stronger and stronger. However, the insulation performance of building walls is not as good as that of buildings in the northern regions where central heating is used for a long time, and the ratio of windows to walls is bigger. So the acceptable floor temperature of occupants based on thermal comfort may be not the same. Low temperature hot water floor radiant heating system which appeared in the early 20th century [1] has received more and more attention especially by the southern people due to the low temperature of hot water, good comfort and energy saving. However, how to create a comfortable indoor environment by the use of floor radiant heating and formulate industry standards remain to be solved.

The European, American, and international standards [2-5]governing the temperature range of radiant floor heating are mostly in the range of 19 to $29{ }^{\circ} \mathrm{C}$. The sources of data are mainly those of Olesen et al [6-7]. from the Technical University of Denmark in the 1970s1980s. While the Chinese standard is $24 / 25 \sim 26 / 27^{\circ} \mathrm{C}$, the upper limit is $28 / 29{ }^{\circ} \mathrm{C}[8]$. The data source can be considered as part of the reference to foreign early research data. However, due to differences in races, living environment and living habits, Asian populations are more tolerant of heat, so the acceptable comfortable floor temperature should be higher than that of European and American people. The Japanese and Korean scholars have confirmed that. In Korea, there is a traditional floor heating method called "ONDOL", which has a comfortable floor surface temperature range of 33.6 38. ${ }^{\circ} \mathrm{C}[9]$. The upper and lower temperature limits when sitting are related to the material of the floor. The neutral temperature of the human body is $32.6{ }^{\circ} \mathrm{C}[10]$. When standing with barefoot, the floor temperature range is $27 \sim 33{ }^{\circ} \mathrm{C}[11]$. Japanese scholars have concluded that the upper and lower limits of acceptable temperature are $31^{\circ} \mathrm{C}$ and $25^{\circ} \mathrm{C}$, respectively, and the optimal floor temperature range is $26 \sim 30^{\circ} \mathrm{C}[12]$. It can be seen that the temperature range obtained by research in Asian regions such as Korea and Japan is higher than the international standard $\left(19 \sim 29^{\circ} \mathrm{C}\right)$.

When using the floor radiant heating, floor contacts the foot directly, and the comfortable air temperature required for different part of human body is different [13]. In the hot environment, head is sensitive to heat discomfort, while feet and hands can easily feel cold and uncomfortable in the cold environment[14]. If staying on the warmer floor for a long time, when the skin temperature of feet is greater than $34{ }^{\circ} \mathrm{C}$, the blood flow is significantly increased [15]. In addition, the increase of skin temperature will relax the capillaries, promote blood circulation, and enhance the oxygen supply of various tissues and organs of the human body [16-17]. Nevertheless, if the ambient temperature around the feet is at a high level for a long time, it is not only harmful to 
patients with cardiovascular disease and diabetes [18], but also has adverse effects on healthy people [19]. Therefore, in determining the upper limit of the floor temperature, both the thermal comfort requirement and the long-term cumulative effect on health should be considered.

Floor radiant heating creates an unsteady indoor environment, comfort temperature is not equal to neutral temperature. That is to say, people who undergo a number of cold environments may prefer warmer floor temperature instead of neutral floor temperature[20-21]. Therefore, as far as the southern region is concerned, it is possible to further increase the upper limit of $29{ }^{\circ} \mathrm{C}$ in the current Chinese standard. Thus, the study focused on the actual heating environment in southern buildings. From the perspective of thermal comfort, combined with the frequency of sick symptoms, an acceptable floor temperature range adapted to the southern region was proposed.

\section{Research methods}

\subsection{Experimental platform}

The experiment was carried out in a capillary radiation laboratory with a floor area of $3 \mathrm{~m}^{*} 1.5 \mathrm{~m}$ and a height of $3 \mathrm{~m}$. The air source heat pump unit and the heating water tank were used to prepare hot water, and the temperature probe was arranged in the water tank to monitor the water temperature in time. The hot water entered the capillary network under the floor in the room for radiant heating, as Figure 1 shows. Floor material was polystyrene board, shown in Figure 2. a), and the wall was made of ordinary brick wall with thermal insulation material, which was similar to the common structure of architecture in southern China.

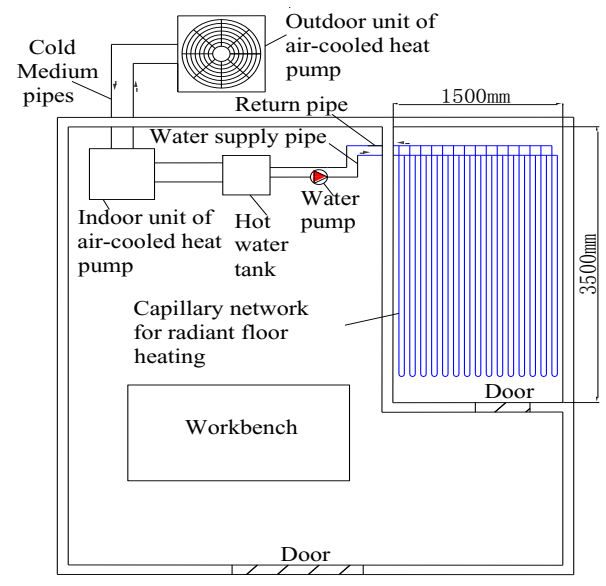

Fig.1. Diagram of the experimental platform.

The indoor air vertical temperature and floor surface temperature were measured by an Agilent 34970A data acquisition instrument with copper-constantan thermocouples. The measurement accuracy after water bath calibration was $\pm 0.1{ }^{\circ} \mathrm{C}$. The measuring points on the floor surface are arranged in three equal parts of the diagonal[8], a total of five $(a, b, c, d, e)$ as Figure 2. b) shows. Point A, B and $\mathrm{C}$ were the position of subjects. The height of the vertical temperature measurement points included $0.1 \mathrm{~m}$ (ankle), $0.6 \mathrm{~m}$ (knee), $1.1 \mathrm{~m}$ (head by sitting), $1.7 \mathrm{~m}$ (head by standing), and $2.5 \mathrm{~m}$ (top of the room), as Figure 2. c) shows. The skin temperature of human body and indoor air relative humidity were measured by HOBO UX100-011 temperature and humidity self-recording instrument, and the measurement accuracy was $\pm 0.21{ }^{\circ} \mathrm{C} ; \pm 2.5 \%$. The measurement points of skin temperature included upper arm, chest, anterior thigh, interior calf, instep and ankle. The measurement time of all parameters were 90 minutes.

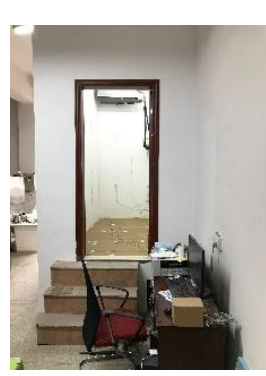

a)

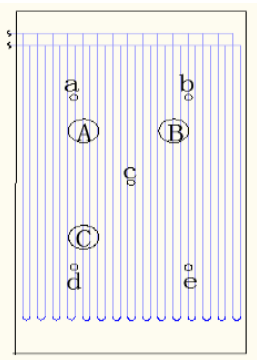

b)

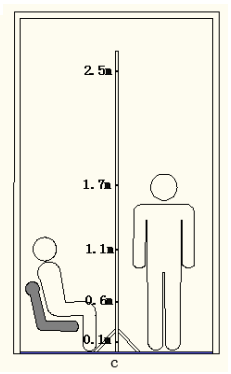

c)
Fig.2. Diagram of Experimental details: a) exterior of the Capillary radiation room, b) measuring points on the floor, c) measuring points of vertical temperature

\subsection{Experimental conditions and procedure}

The experiment was carried out in January 2018 in Chongqing, China. Chongqing is a typical city in southern China, which is located in the hot summer and cold winter climate zone. The outdoor temperature during the experiment was from $2{ }^{\circ} \mathrm{C}$ to $8{ }^{\circ} \mathrm{C}$. Experimental conditions were designed with six different floor temperatures. The floor surface temperature was controlled by varying the temperature of water $\left(t_{\mathrm{w}}\right)$ flowing underneath the floor, and it ranged from $t_{w}=$ $30{ }^{\circ} \mathrm{C}$ to $55{ }^{\circ} \mathrm{C}$ at $5{ }^{\circ} \mathrm{C}$ intervals. The background temperature is maintained at a neutral temperature of 20 to $22{ }^{\circ} \mathrm{C}$ and relative humidity of $50 \%$.

Before the experiment, the subjects were asked to be familiar with the experiment requirements and questionnaire in the natural ventilation room, clothing is about 1.2 clo.Then entering the floor heating room after eliminating the previous thermal experience by resting for about 20 minutes. At the beginning of the experiment, the subject took off his shoes and stepped on the floor wearing socks. Subjects could read books or use mobile phones, but are not allowed to communicate and discuss about thermal comfort. During the experiment, subjects were asked to fill out the questionnaire and measured physiological parameters at intervals of $5 \mathrm{~min}$ or 10 min.At the same time, the operator recorded environmental parameters, as shown in Figure 3.

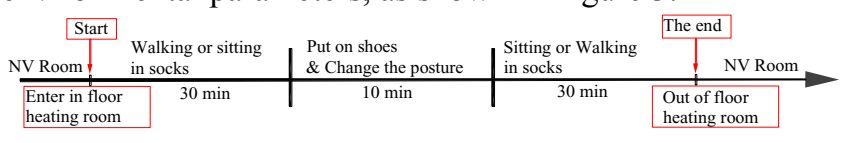

Fig.3. Experimental procedures 
To avoid the effects of posture on thermal comfort, subjects were randomly assigned to two groups: first standing, sitting back, or sitting first and then standing. Due to the temperature drop of the hot water pipe network and the heat dissipation of floor material, the final floor surface temperature was averaged by the actual temperature measured by five points. Thus the actual floor surface temperature were used to analyse in the paper.

\subsection{Subjects}

Twelve healthy college students participated in the experiment, with a male to female ratio of 1:1. All of the subjects are currently living in Chongqing, China, most of them are born in southern China, only a few are from the central region, and more importantly, they have no thermal experience of central heating in winter. Their information is listed in Table 1 . It can be seen that women will choose more diversified heating methods in winter, for instance, combining air conditioning and auxiliary heating equipment to achieve better thermal comfort.

Table 1. Information of Subjects

\begin{tabular}{|c|c|c|c|c|c|}
\hline Group & Age & Height (cm) & Weight (kg) & Body fat rate $(\%)$ & Heating method in winter (Proportion \%) \\
\hline \multirow{3}{*}{ Female } & \multirow{3}{*}{$23 \pm 1$} & \multirow{3}{*}{$161.7 \pm 5.2$} & \multirow{3}{*}{$52.9 \pm 6.0$} & \multirow{3}{*}{$26.2 \pm 3.9$} & Air conditioning heating $(66.7 \%)$ \\
\hline & & & & & Local heating (16.6\%) \\
\hline & & & & & Air conditioning heating + Local heating $(16.6 \%)$ \\
\hline \multirow[t]{2}{*}{ Male } & \multirow[t]{2}{*}{$23 \pm 1$} & \multirow[t]{2}{*}{$177.3 \pm 4.6$} & \multirow[t]{2}{*}{$68.7 \pm 8.4$} & \multirow[t]{2}{*}{$19.6 \pm 3.9$} & Air conditioning heating $(66.7 \%)$ \\
\hline & & & & & Local heating $(33.3 \%)$ \\
\hline \multirow[t]{3}{*}{ All } & \multirow[t]{3}{*}{$23 \pm 1$} & \multirow[t]{3}{*}{$169.5 \pm 9.2$} & \multirow[t]{3}{*}{$60.8 \pm 10.7$} & \multirow[t]{3}{*}{$22.9 \pm 5.1$} & Air conditioning heating $(66.7 \%)$ \\
\hline & & & & & Local heating $(25 \%)$ \\
\hline & & & & & Air conditioning heating + Local heating $(8.3 \%)$ \\
\hline
\end{tabular}

\subsection{Questionnaires}

Questionnaires overed the thermal sensation vote (TSV), thermal pleasure vote (TPV) and a variety of sick symptom. Both the overall perception and local perception were evaluated, especially the heat perception of the feet.Thermal sensation was assessed using the ASHRAE seven-point thermal sensation scale -3 cold, -2 cool, -1 slightly cool, 0 neutral, +1 slightly warm, +2 warm, +3 hot. TPV: -3 very unpleasant, -2 unpleasant, -1 slightly unpleasant, 0 indifferent, +1 slightly pleasant, +2 pleasant, +3 very pleasant [22]. Sick symptom including: headache, dizzy, foot pain, pedal numbness, fatigue and lethargy, which is evaluated by four level: No,slightly,obviously, strongly. In addition. The subjects were also asked whether it was difficult to concentrate and do not want to study.

\section{Result and discussion}

\subsection{Thermal environment monitored}

For the sake of analyzing whether the vertical temperature difference of the environment would cause thermal discomfort, the test was repeated four times for each working condition, and the surface temperature of the floor corresponding to the six different water supply temperatures was shown in the Table 2.
Table 2. Actual floor temperature

\begin{tabular}{cc}
\hline $\begin{array}{c}\text { Water supply } \\
\text { temperature }\left({ }^{\circ} \mathrm{C}\right)\end{array}$ & $\begin{array}{c}\text { Floor surface } \\
\text { temperature }\left({ }^{\circ} \mathrm{C}\right)\end{array}$ \\
\hline 55 & $36.4 \pm 0.3$ \\
50 & $33.9 \pm 0.5$ \\
45 & $31.8 \pm 0.3$ \\
40 & $29.6 \pm 0.4$ \\
35 & $27.4 \pm 0.4$ \\
30 & $25.8 \pm 0.2$ \\
\hline
\end{tabular}

The temperature at different vertical heights is shown in the figure 4.It can be seen that when $t w=55^{\circ} \mathrm{C}$, $\mathrm{tw}=50^{\circ} \mathrm{C}, \mathrm{tw}=45^{\circ} \mathrm{C}$, the air in the room was hot below but cold above. While when $\mathrm{tw}=40^{\circ} \mathrm{C}, \mathrm{tw}=35^{\circ} \mathrm{C}$, and $\mathrm{tw}=30^{\circ} \mathrm{C}$, the room was cold below but hot above. However, the vertical temperature difference (temperature difference between the head and the foot) of all conditions didn't exceed $3{ }^{\circ} \mathrm{C}$, which met the thermal comfort requirement [3]. 


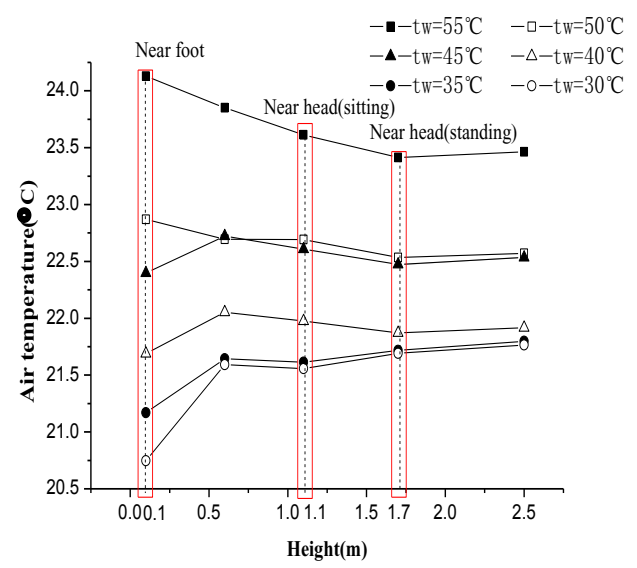

Fig.4. Vertical temperature distribution of indoor air

\subsection{Skin temperature, TSV and TPV of foot}

Took the average of the instep and ankle temperature as the skin temperature of the foot. The skin temperature of foot when sitting was higher than standing, and it showed a more significant correlation with the floor temperature. When the floor temperature was less than $34.5^{\circ} \mathrm{C}$, the TSV of standing was hotter than sitting. While after $34.5^{\circ} \mathrm{C}$, the thermal sensation of sitting was hotter than that of standing, and the rising speed of TSV increased with the floor temperature rising. The TPV of standing was better than that of sitting before the floor temperature was $34^{\circ} \mathrm{C}$, but it obviously decreased after $34^{\circ} \mathrm{C}$, and the TPV of sitting increased as the floor temperature increased.

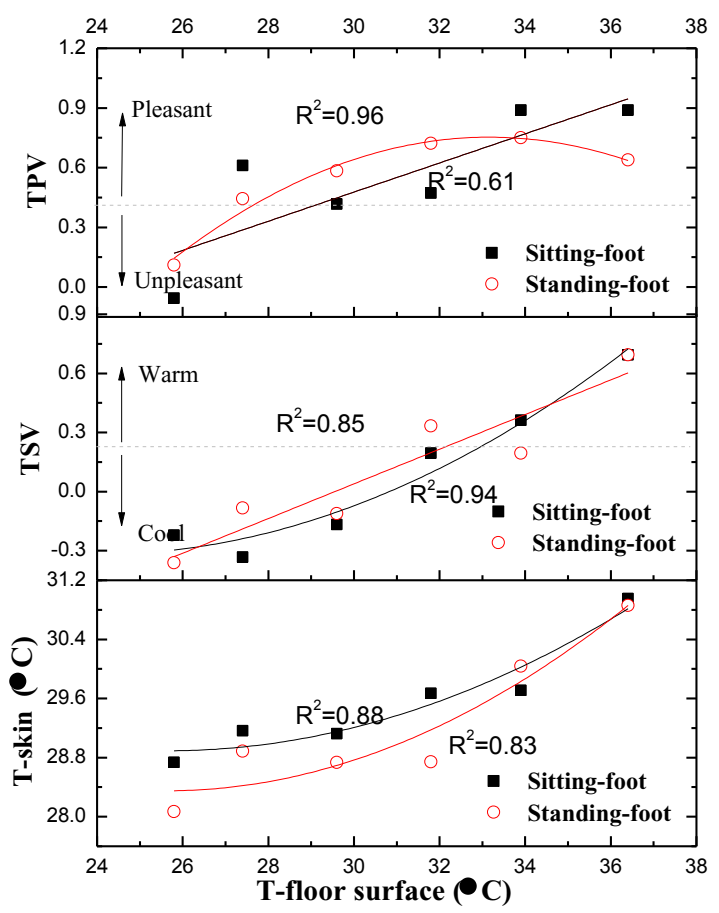

Fig.5. Skin temperature, TSV and TPV of foot with floor temperature

\subsection{MST, TSV and TPV of overall and head}

The mean skin temperature(MST) was calculated by weighting the local skin temperature. The formula[23] is as follows :

$M S T=0.3 T_{s k, u a}+0.3 T_{s k, c h}+0.2 T_{s k, a t}+0.2 T_{s k, a c}$

Where $T_{s k, u a}$ is temperature of upper arm, ${ }^{\circ} \mathrm{C} . T_{s k, c h}$ is temperature of chest, ${ }^{\circ} \mathrm{C}$. $T_{s k, a t}$ is temperature of anterior thigh, ${ }^{\circ} \mathrm{C}$. $T_{s k, a c}$ is temperature of anterior calf, ${ }^{\circ} \mathrm{C}$.

Head is the farthest part from the heating floor. Furthermore, the TSV and TPV of head have a greater impact on the work and learning efficiency of occupiers. As can be seen from Figure 6, the MST changed little, and the difference was within $1.5{ }^{\circ} \mathrm{C}$. There was a significant positive correlation between the TSV and the floor temperature. When sitting, the TSV of overall and head both rose slowly with the increased of floor temperature, and the rate of change was basically unchanged. However, in standing condition, the increase rate of overall TSV was faster first and then slower, while the head TSV showed a slowly rising trend. In both postures, overall TPV and head TPV were relatively less correlated with floor temperature, especially overall. For the head, the TPV decreased as the floor temperature increased. When the floor temperature exceeds $31{ }^{\circ} \mathrm{C}$, the rate of decline in standing position was significantly accelerated.

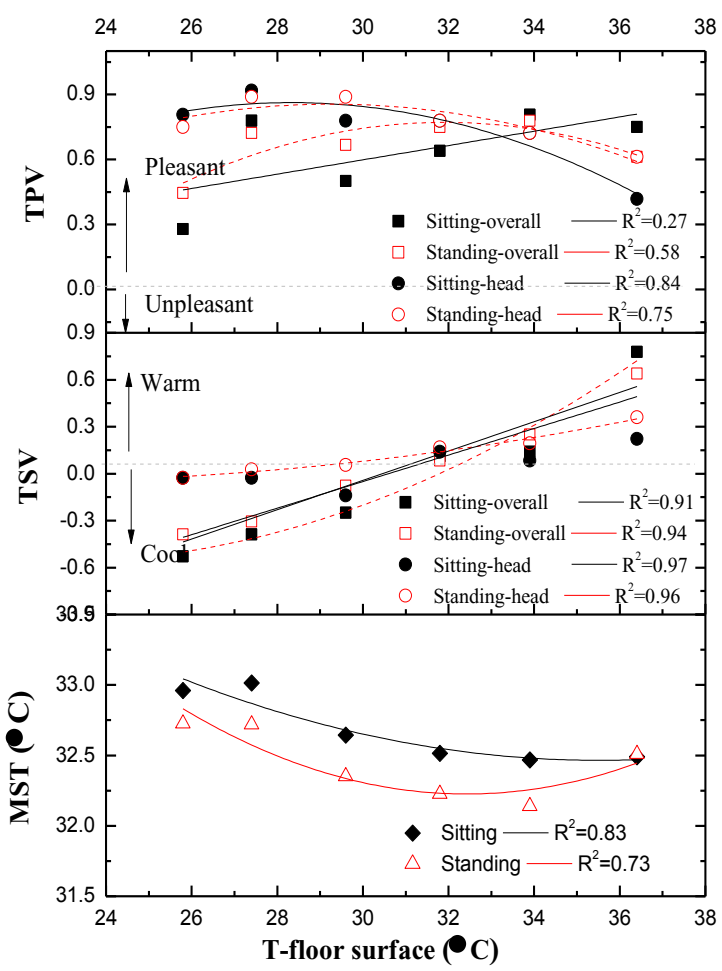

Fig.6. MST, TSV and TPV of overall and head with floor temperature 


\subsection{Percentage Dissatisfied (PD) of cool and warm}

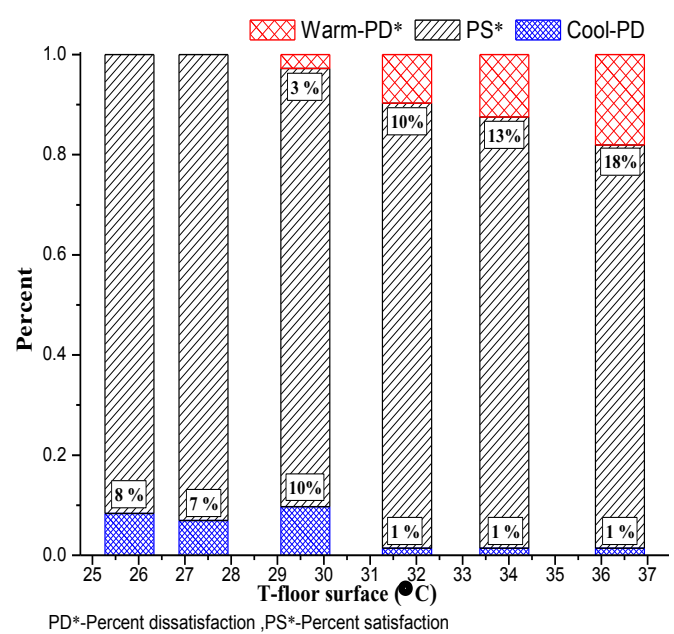

Fig.7. PD of cool and warm with floor temperature by sitting Thermal discomfort is first shown by people who have a thermal sensation higher than +2 or below -2 [24]. Therefore, it was determined to be dissatisfied when felt obvious uncomfortable in this experiment. The percentage dissatisfied of warm(warm-PD) was defined as the percentage of subject's TSV was greater than or equal to +2 . Analogous to the warm-PD, cool-PD meant subject's TSV was less than or equal to -2 . In both postures, the rate of cold dissatisfaction decreased as the temperature increased. When the floor temperature exceeded $29.5{ }^{\circ} \mathrm{C}$, the thermal dissatisfaction rate appeared and rose. Moreover, the cold dissatisfaction rate of sitting posture was obviously higher than that of standing posture, and the thermal dissatisfaction rate is also slightly higher.

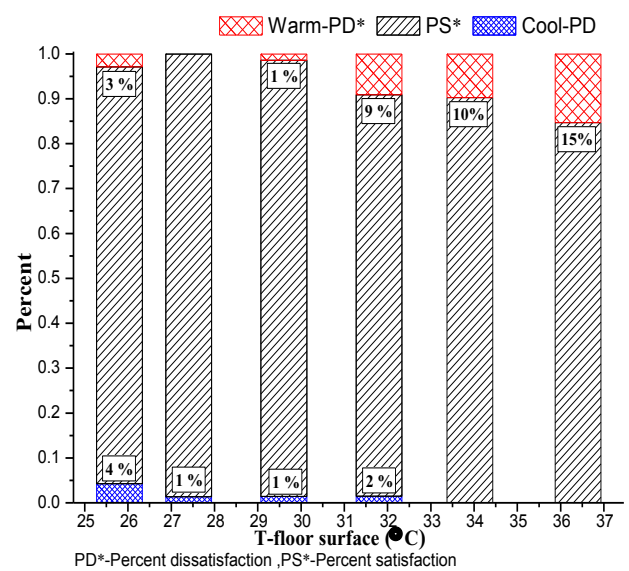

Fig.8. PD of cool and warm with floor temperature by standing

\subsection{Sick symptom}

In the experiment, headache, dizzy were unified as head discomfort. Foot pain, pedal numbness were foot discomfort. Fatigue and lethargy were poor mental state. The results are shown in the table 3.
Table 3.a) Sick symptom with floor temperature by sitting

\begin{tabular}{|c|c|c|c|c|c|c|c|}
\hline \multirow{2}{*}{$\begin{array}{c}\text { Sick } \\
\text { symptom }\end{array}$} & \multirow[b]{2}{*}{ Level } & \multicolumn{6}{|c|}{ Floor temperature $\left({ }^{\circ} \mathbf{C}\right)$} \\
\hline & & $\begin{array}{c}25 . \\
8\end{array}$ & $\begin{array}{c}27 . \\
4\end{array}$ & $\begin{array}{c}29 . \\
6\end{array}$ & $\begin{array}{c}31 . \\
8\end{array}$ & $\begin{array}{c}33 . \\
9\end{array}$ & $\begin{array}{r}36 . \\
4\end{array}$ \\
\hline \multirow{3}{*}{$\begin{array}{c}\text { Head } \\
\text { symptom }\end{array}$} & O* & 0 & 0 & 0 & 0 & 0 & 0 \\
\hline & $\mathrm{S}^{*}$ & 0 & 0 & $\begin{array}{c}0.0 \\
1\end{array}$ & $\begin{array}{c}0.0 \\
1\end{array}$ & $\begin{array}{c}0.0 \\
7\end{array}$ & 0.1 \\
\hline & $\mathrm{N}^{*}$ & 1 & 1 & $\begin{array}{c}0.9 \\
9\end{array}$ & $\begin{array}{c}0.9 \\
9\end{array}$ & $\begin{array}{c}0.9 \\
3\end{array}$ & 0.9 \\
\hline \multirow[b]{2}{*}{$\begin{array}{c}\text { Foot } \\
\text { symptom }\end{array}$} & $\mathrm{O}^{*}$ & 0 & 0 & 0 & 0 & 0 & 0 \\
\hline & $\mathrm{N}^{*}$ & $\begin{array}{c}0.0 \\
7 \\
0.9 \\
3\end{array}$ & 0 & $\begin{array}{c}0.0 \\
7 \\
0.9 \\
3\end{array}$ & $\begin{array}{c}0.0 \\
4 \\
0.9 \\
6\end{array}$ & $\begin{array}{c}0.0 \\
3 \\
0.9 \\
7\end{array}$ & $\begin{array}{c}0.0 \\
3 \\
0.9 \\
7\end{array}$ \\
\hline \multirow{3}{*}{$\begin{array}{l}\text { Poor } \\
\text { mental } \\
\text { state }\end{array}$} & $\mathrm{O}^{*}$ & 0 & $\begin{array}{c}0.0 \\
1\end{array}$ & 0 & $\begin{array}{c}0.0 \\
3\end{array}$ & $\begin{array}{c}0.0 \\
4\end{array}$ & $\begin{array}{c}0.0 \\
3\end{array}$ \\
\hline & $\mathrm{S}^{*}$ & $\begin{array}{c}0.2 \\
4\end{array}$ & $\begin{array}{c}0.2 \\
9\end{array}$ & $\begin{array}{c}0.3 \\
3\end{array}$ & $\begin{array}{c}0.3 \\
1\end{array}$ & $\begin{array}{c}0.3 \\
2\end{array}$ & 0.1 \\
\hline & $\mathrm{N}^{*}$ & $\begin{array}{c}0.7 \\
6\end{array}$ & $\begin{array}{c}0.6 \\
9\end{array}$ & $\begin{array}{c}0.6 \\
7\end{array}$ & $\begin{array}{c}0.6 \\
7\end{array}$ & $\begin{array}{c}0.6 \\
4\end{array}$ & $\begin{array}{c}0.8 \\
8\end{array}$ \\
\hline $\begin{array}{l}\text { Difficult } \\
\text { to }\end{array}$ & $\mathrm{O}^{*}$ & 0 & $\begin{array}{c}0.0 \\
1\end{array}$ & 0 & 0 & $\begin{array}{c}0.0 \\
4\end{array}$ & $\begin{array}{c}0.0 \\
1\end{array}$ \\
\hline $\begin{array}{c}\text { concentrat } \\
\text { e and do }\end{array}$ & $\mathrm{S}^{*}$ & $\begin{array}{c}0.2 \\
9\end{array}$ & $\begin{array}{c}0.2 \\
8\end{array}$ & $\begin{array}{c}0.1 \\
9\end{array}$ & $\begin{array}{c}0.2 \\
8\end{array}$ & $\begin{array}{c}0.3 \\
1\end{array}$ & $\begin{array}{c}0.1 \\
7\end{array}$ \\
\hline $\begin{array}{l}\text { not want } \\
\text { to study }\end{array}$ & $\mathrm{N}^{*}$ & $\begin{array}{c}0.7 \\
1\end{array}$ & $\begin{array}{c}0.7 \\
1\end{array}$ & $\begin{array}{c}0.8 \\
1\end{array}$ & $\begin{array}{c}0.7 \\
2\end{array}$ & $\begin{array}{c}0.6 \\
5\end{array}$ & $\begin{array}{c}0.8 \\
2\end{array}$ \\
\hline
\end{tabular}

O*- Obviously, S* -Slightly, N*- No

Table 3.b) Sick symptom with floor temperature by standing

\begin{tabular}{|c|c|c|c|c|c|c|c|}
\hline \multirow{2}{*}{$\begin{array}{c}\text { Sick } \\
\text { symptom }\end{array}$} & \multirow{2}{*}{$\begin{array}{c}\text { Lev } \\
\text { el }\end{array}$} & \multicolumn{6}{|c|}{ Floor temperature $\left({ }^{\circ} \mathbf{C}\right)$} \\
\hline & & $\begin{array}{c}25 . \\
8\end{array}$ & $\begin{array}{c}27 . \\
4\end{array}$ & $\begin{array}{c}29 . \\
6\end{array}$ & $\begin{array}{c}31 . \\
8\end{array}$ & $\begin{array}{c}33 . \\
9\end{array}$ & 36.4 \\
\hline \multirow{3}{*}{$\begin{array}{c}\text { Head } \\
\text { symptom }\end{array}$} & $\mathrm{O}^{*}$ & 0 & 0 & 0 & 0 & 0 & 0 \\
\hline & $\mathrm{S}^{*}$ & 0 & 0 & $\begin{array}{c}0.0 \\
7\end{array}$ & 0 & $\begin{array}{c}0.0 \\
3\end{array}$ & 0.06 \\
\hline & $\mathrm{N}^{*}$ & 1 & 1 & $\begin{array}{c}0.9 \\
3 \\
\end{array}$ & 1 & $\begin{array}{c}0.9 \\
7 \\
\end{array}$ & 0.94 \\
\hline \multirow{3}{*}{$\begin{array}{c}\text { Foot } \\
\text { symptom }\end{array}$} & $\mathrm{O}^{*}$ & $\begin{array}{c}0.0 \\
1\end{array}$ & 0 & 0 & $\begin{array}{c}0.0 \\
1\end{array}$ & $\begin{array}{c}0.0 \\
1\end{array}$ & 0.06 \\
\hline & $\mathrm{S}^{*}$ & $\begin{array}{c}0.0 \\
8\end{array}$ & $\begin{array}{c}0.0 \\
7\end{array}$ & 0.1 & $\begin{array}{c}0.0 \\
7\end{array}$ & $\begin{array}{c}0.1 \\
1\end{array}$ & 0.08 \\
\hline & $\mathrm{N}^{*}$ & 0.9 & $\begin{array}{c}0.9 \\
3 \\
\end{array}$ & 0.9 & $\begin{array}{c}0.9 \\
2 \\
\end{array}$ & $\begin{array}{c}0.8 \\
8 \\
\end{array}$ & 0.86 \\
\hline \multirow{3}{*}{$\begin{array}{l}\text { Poor mental } \\
\text { state }\end{array}$} & $\mathrm{O}^{*}$ & 0 & 0 & 0 & $\begin{array}{c}0.0 \\
7\end{array}$ & 0 & 0.01 \\
\hline & $\mathrm{S}^{*}$ & $\begin{array}{c}0.2 \\
2\end{array}$ & $\begin{array}{c}0.2 \\
6\end{array}$ & $\begin{array}{c}0.3 \\
6\end{array}$ & $\begin{array}{c}0.2 \\
2\end{array}$ & $\begin{array}{c}0.2 \\
6\end{array}$ & 0.22 \\
\hline & $\mathrm{N}^{*}$ & $\begin{array}{c}0.7 \\
8 \\
\end{array}$ & $\begin{array}{c}0.7 \\
4 \\
\end{array}$ & $\begin{array}{c}0.6 \\
4 \\
\end{array}$ & $\begin{array}{c}0.7 \\
1 \\
\end{array}$ & $\begin{array}{c}0.7 \\
4 \\
\end{array}$ & 0.76 \\
\hline \multirow{3}{*}{$\begin{array}{l}\text { Difficult to } \\
\text { concentrate } \\
\text { and do not } \\
\text { want to } \\
\text { study }\end{array}$} & $\mathrm{O}^{*}$ & 0 & 0 & 0 & $\begin{array}{c}0.0 \\
4\end{array}$ & $\begin{array}{c}0.0 \\
1\end{array}$ & 0 \\
\hline & $\mathrm{S}^{*}$ & $\begin{array}{c}0.2 \\
1\end{array}$ & $\begin{array}{c}0.2 \\
6\end{array}$ & $\begin{array}{c}0.2 \\
9\end{array}$ & $\begin{array}{c}0.2 \\
2\end{array}$ & 0.4 & 0.18 \\
\hline & $\mathrm{N}^{*}$ & $\begin{array}{c}0.7 \\
9\end{array}$ & $\begin{array}{c}0.7 \\
4\end{array}$ & $\begin{array}{c}0.7 \\
1\end{array}$ & $\begin{array}{c}0.7 \\
4\end{array}$ & $\begin{array}{c}0.5 \\
8\end{array}$ & 0.82 \\
\hline
\end{tabular}

In the standing position, as the temperature decreases, the head discomfort was reduced. Simultaneously, the foot discomfort, poor mental state and study status showed a trend of decreasing first and then increasing, and the lower limit temperature was about $29.5^{\circ} \mathrm{C}$. However, when sitting, head discomfort decreased with 
decreasing floor temperature and was lower than standing. The lower limit temperature of the foot was $29.5^{\circ} \mathrm{C}$ and $33^{\circ} \mathrm{C}$ for mental state and study status.

\section{Conclusions and limitation}

After the regression analysis of skin temperature, TSV, TPV and the incidence of sick symptoms, the main conclusions were as follows :

Different levels of temperature stratification appear on different floor surface temperatures, and the higher the temperature, the more obvious the sick phenomenon. The floor temperature directly affected the skin temperature and thermal comfort of the foot, and presented a statistically significant relationship with the overall and head thermal sensation.

According to the linear fitting and polynomial fitting, took the thermal sensation voting value of -0.5 to +0.5 for an acceptable range. It was calculated that the acceptable floor surface temperature of sitting was $26.1{ }^{\circ} \mathrm{C} \sim 34.3{ }^{\circ} \mathrm{C}$, and $24.6{ }^{\circ} \mathrm{C} \sim 34.7^{\circ} \mathrm{C}$ for standing.Considering the local thermal comfort of the head and the long-term thermal exposure cumulative effect on health, this experiment suggested that the upper limit of the floor temperature should be $31^{\circ} \mathrm{C}$.

Only 12 subjects were involved in the experiment and the sample size of which is small, lead to a weak conclusion. Therefore, if the general applicability of national standards is taken into account, the sample size should be expanded in subsequent experiments to determine the upper and lower limits of the acceptable floor temperature range.

\section{Acknowledgements}

This research is supported by The UK-China collaborative research project "Low carbon climateresponsive Heating and Cooling of Cities (LoHCool)" supported by the National Natural Science Foundation of China (NSFC Grant No. 51561135002) and UK Engineering and Physical Sciences Research Council (EPSRC Grant No. EP/N009797/1), and the Fundamental Research Funds for the Central Universities (Grant No. 2018CDJDCH0015) and the 111 Project (No. B13041).

\section{Abbreviations}

\begin{tabular}{|c|c|c|}
\hline Symbol & Definition & Unit/ Range \\
\hline tw & Water supply temperature & ${ }^{\circ} \mathbf{C}$ \\
\hline TSV & Thermal sensation vote & $-3 \sim+3$ \\
\hline TPV & Thermal pleasure vote & $-3 \sim+3$ \\
\hline MST & Mean skin temperature & ${ }^{\circ} \mathbf{C}$ \\
\hline PD & Percentage dissatisfied & $\%$ \\
\hline PS & Percentage satisfied & $\%$ \\
\hline
\end{tabular}

\section{References}

1. Bojic, Milorad, Cvetkovic, Dragan, Bojic, Ljubisa et al. Decreasing energy use and influence to environment by radiant panel heating using different energy sources. Applied energy, 2015, 138(Jan. 15): 404-413

2. Ashrae. ANSI/ ASHRAE Standard 55-2013: Thermal Environmental Conditions for Human Occupancy. Atlanta, Ashrae, 2013.

3. ISO. EN ISO 7730:2005, Ergonomics of the thermal environment - Analytical determination and interpretation of thermal comfort using calculation of the PMV and PPD indices and local thermal comfort criteria. Geneva, Iso, 2005

4. ISO. PD ISO TS 13732-2: 2001 Ergonomics of the thermal environment-Methods for the assessment of human responses to contact with surfaces. Human contact with surfaces at moderate temperature. Geneva, Iso, 2001

5. ISO. EN ISO 13732-1:2006 Ergonomics of the thermal environment -Methods for the assessment of human responses to contact with surfaces. Part 1 : Hot surfaces . Geneva, Iso, 2008

6. Olesen B W. THERMAL COMFORT REQUIREMENTS FOR FLOORS OCCUPIED BY PEOPLE WITH BARE FEET. Ashrae Transactions. 1977, 83: 41-57.

7. Olesen B W, Mortensen E, Thorshauge J, et al. Thermal comfort in a room heated by different methods. Ashrae Transactions. 1980, 86(1): 34-48.

8. Chongqing University, China Academy of Building Research. GB/T50785-2012 "Evaluation Standards for Indoor Thermal and Humid Environment of Civil Buildings" . Beijing: China Building Industry Press, 2012.

9. Sohn J Y. THE STATE OF THERMAL SENSATION RESEARCHES IN KOREA AND THERMAL COMFORT IN ONDOL SPACE. Human thermal environment report. 1986, 10: 93-98

10. Song G S. Buttock responses to contact with finishing materials over the ONDOL floor heating system in Korea. Energy \& Buildings. 2005, 37(1): 65-75.

11. Song G S. Effect of floor surface temperature on blood flow and skin temperature in the foot. Indoor Air. 2008, 18(6): 511-520.

12. Zhang L, Emura K, Nakane Y. A proposal of optimal floor surface temperature based on survey of literatures related to floor heating environment in Japan. Applied Human Science. 1998 Mar;17(2):61-66.

13. Zhang H. Human thermal sensation and comfort in transient and non-uniform thermal environment. California: UC Berkeley, 2003.

14. Mishra A K, Loomans M G L C, Hensen J L M. Thermal comfort of heterogeneous and dynamic indoor conditions -An overview. Building \& Environment. 2016, 109: 82-100.

15. Gook-Sup Song. Effect of floor surface temperature on blood flow and skin temperature in the foot. Indoor Air. 2008;18:511-520. 
16. Levick J. R, Michel C. C. The effects of position and skin temperature on the capillary pressures in the fingers and toes. The Journal of Physiology. 1978, 274(1): 97-109.

17. Kräuchi Kurt. Warm feet promote the rapid onset of sleep. Nature. 1999, 401:36-37

18. Sun Pi-Chang. Relationship of skin temperature to sympathetic dysfunction in diabetic at-risk feet. Diabetes Research and Clinical Practice. 2006, 73(1):41-46.

19. Assanasen Paraya. Warming of feet elevates nasal mucosal surface temperature and reduces the early response to nasal challenge with allergen. Journal of Allergy and Clinical Immunology. 1999, 104(2):285-293.

20. Liu H, Wu Y, Li B, et al. Seasonal variation of thermal sensations in residential buildings in the
Hot Summer and Cold Winter zone of China. Energy \& Buildings. 2017, 140: 9-18.

21. Brager G S, De Dear R J. Thermal adaptation in the built environment: a literature review. Energy and Buildings. 1998, 27(1): 83-96.

22. PARKINSON, T., DE DEAR, R. \& CANDIDO, C. Thermal pleasure in built environments: alliesthesia in different thermoregulatory zones. Building Research and Information, 2016, 44, 20-33.

23. Ramanathan N L. A new weighting system for mean surface temperature of the human body. Journal of Applied Physiology. 1964, 19(3): 531-533.

24. GAGGA, A P.; STOLWIJK, A J., and HARDY, J D. Comfort and thermal sensations and associated physiological reponses at various ambient temperatures.Environment Research. 1967,1:1-20. 